\title{
КОЕФІЦІЄНТИ ФЕНОТИПОВОЇ КОНСОЛІДАЦІІ ПОКАЗНИКУ БАГАТОПЛІДНОСТІ СВИНОМАТОК УЕЛЬСЬКОї ПОРОДИ
}

\author{
Церенюк Олександр Миколайович \\ доктор сільськогосподарських наук, доцент \\ Інститут тваринництва НАAН \\ ORCID: 0000-0003-4797-9685 \\ Email: tserenyuk@gmail.com
}

\author{
Мартинюк Ірина Миколаївна \\ кандидат сільськогосподарських наук, ст. науковий співробітник \\ Інститут тваринництва НААН \\ ORCID: 0000-0002-3675-124X
} Email: martinyuk.i.n.2015@gmail.com

Акімов Олександр Валентинович кандидат сільськогосподарських наук, ст. науковий співробітник Інститут тваринництва НАAН ORCID: 0000-0002-1938-0459

Email: akimov.kharkiv@gmail.com Шкавро Наталія Миколаївна
кандидат сільськогосподарських наук, ст. науковий співробітник
Інститут тваринництва HAAH
ORCID: 0000-0002-9768-1847
Email: shkavro@ukr.net

Хмельничий Леонтій Михайлович доктор сільськогосподарських наук, профресор Сумський національний аграрний університет ORCID: 0000-0001-5175-1291 Email: khmelnychy@ukr.net

Метою досліджень, результати якої викладені у статті, було вивчення впливу віку свиноматок і кнурів на їх багатоплідність із урахуванням сезону року та віку тварин. Дослідження проводилися в дослідному господарстві ДП ДГ „Гонтарівка” Вовчанського району Харківської області. Для відтворення поголів'я у господарстві використовують природне парування свиноматок. Осіменіння свиноматок було проведено згідно зі схемою досліджень. Для проведення експериментальної роботи на свинофермі племзаводу було відібрано 35 голів основних свиноматок та 4 кнури породи уельс різного віку та різної живої ваги. Було сформовано чотири групи маток. 3 метою вивчення впливу сезону року на продуктивність свиноматок, першу серію досліджень провели восени, другій серію - навесні за тією ж схемою. Використовували у обох серіях досліджень одних і тих самих тварин. По різних групах тварин багатоплідність коливалась в межах від 10,56 до 11,78 голів. Краща група (матки у віці 18 міс. за зимових опоросів) перевершувала рівень багатоплідності гіршої групи (матки у віці 24 міс. за літніх опоросів) на 11,55 \% ( $<$ < 0,05). В той же час, влітку було отримано на 1,81 \% більші значення показника багатоплідності (11,26士0,189 порося на матку), порівняно з зимовими опоросами $(11,06 \pm 0,189$ порося на матку), хоча й різниия була не вірогідною. В межах окремих серій досліджень, кращі значення багатоплідності були отримані за використання більш вікових кнурів (48 міс.), хоча й різниці також були не вірогідними. Вірогідні розбіжності встановлено між молодими матками (18 міс.), що були осімінені дорослими кнурами (48 міс) за літніх опоросів, та молодими матками (18 міс.), що були осімінені молодими кнурами (18 міс.) за зимових опоросів. Ці розбіжності були на рівні 4,68 \% ( $p<0,05)$. Відносно консолідований показник багатоплідності (за визначення коефріцієнтів френотипової консолідованості обома способами) було отримано лише по одній групі тварин - свиноматок середнього віку (24 міс.) за їх осіменіння кнурами середнього віку (24 міс.) за літніх опоросів. Найменш консолідованими (за визначення коефріцієнтів фенотипової консолідованості обома способами) були показники багатоплідності у вікових маток (48 міс.) за їх осіменіння віковими кнурами (48 міс.) як у літній так і у зимовий періоди.

Ключові слова: свинарство, свиноматки, відтворна здатність, багатоплідність, коефріцієнти френотипової консолідації, сезони року, вік тварин.

DOI: https://doi.org/10.32845/bsnau.Ivst.2019.1-2.15

Свинарство є одною 3 провідних галузей тваринництва від якої в значній мірі залежить вирішення питання забезпечення населення високоцінним білковим продуктом тваринного походження. Попит на продукти тваринництва значною мірою зумовлено зростанням чисельності населення, його платоспроможністю, що й спонукало до нарощення

Вісник Сумського національного аграрного університету 
виробництва м'яса у світі за останні три десятиліття майже втричі. Така тенденція буде продовжуватися і надалі, оскільки попит зростає саме на білкову продукцію тваринного походження [1-4]. Нарощування виробництва ґрунтується на том, що в останні десятиріччя у вітчизняному тваринництві, і зокрема у свинарстві досягнуто значного прогресу [5-6]. Підвищення ефективності виробництва свинини відбувається за рахунок вдосконалення по окремих складових. Не $є$ винятком і такий важливий елемент як відтворна здатність свиноматок [7-11].

Зусилля науковців та виробничників спрямовуються на збільшення кількості поросят, отриманих від однієї свиноматки впродовж року. При розроблені сучасних програм селекції суттєва увага зосереджується насамперед на покращенні відтворювальних ознак свиноматок [12-13].

Сучасні тенденції до зміни клімату потребують приділяти більше уваги до вивчення продуктивності свиноматок під впливом окремих паратипових факторів. Хоча й існує думка про відсутність такого впливу [14]. В той же час відтворна здатність свиноматок належить до ознак із низьким рівнем успадковування, вплив на яку паратипових факторів є значним [15-17].

Одним 3 головних показників, що характеризує відтворну здатність свиноматок $є$ багатоплідність свиноматок. Доведено наявність високих та позитивних кореляцій між кількістю поросят та масою гнізда як при народженні, так і при відлученні [18-21].

Метою роботи було вивчення впливу віку свиноматок і кнурів на їх багатоплідність із урахуванням сезону року та віку тварин.

Матеріали та методи досліджень. Дослідження проводилися в дослідному господарстві ДП ДГ „Гонтарівка” Вовчанського району Харківської області, на базі племінної ферми з утримання свиней породи уельс впродовж 20162017 років. Для відтворення поголів'я у господарстві використовують природне парування свиноматок. Проведені дослідження були продовженням робіт, (Мартинюк І. М., Бугров О. Д., 2015 р.) [22] розпочатих на цьому стаді, з вивченням більш широкого діапазону вікових поєднань кнурів і свиноматок та впливу сезону року на показник багатоплідність та його фенотипову консолідованість. Дослідження були проведені ґрунтуючись на традиційних підходах [23]

Осіменіння свиноматок було проведено згідно до схеми досліджень (табл. 1).

\section{1. Схема досліджень}

\begin{tabular}{|c|c|c|c|c|c|}
\hline \multicolumn{2}{|c|}{ Перша серія (зимові опороси) } & \multicolumn{2}{|c|}{ Друга серія (літні опороси) } & \multicolumn{2}{|c|}{ Вік тварин, міс } \\
\hline & & & & свиноматок & кнурів \\
\hline група тварин & кількість маток у групі, гол & група тварин & кількість маток у групі, гол & & \\
\hline 1 & 9 & $\mathrm{~V}$ & 7 & 48 & 48 \\
\hline II & 9 & $\mathrm{VI}$ & 10 & 18 & 48 \\
\hline III & 8 & $\mathrm{VII}$ & 9 & 24 & 24 \\
\hline IV & 9 & VIII & 9 & 18 & 18 \\
\hline
\end{tabular}

Для проведення експериментальної роботи на свинофермі племінного заводу було відібрано 35 голів основних свиноматок та 4 кнури породи уельс різного віку та різної живої ваги. Було сформовано чотири групи маток. 3 метою вивчення впливу сезону року на продуктивність свиноматок, першу серію досліджень провели восени, другій серію навесні за тією ж схемою. Використовували у обох серіях досліджень одних і тих самих тварин (як батьківську так і материнську складову).

Осіменіння маток проводилось двічі в одну охоту: перший раз через 18-20 годин після встановлення охоти, повторно - через 12-18 годин. В перший період поросності матки утримувались групами по 7-10 голів. За півтора місяця до опоросу свиноматки були розміщені по 4-5 голів у станку, а за тиждень до опоросу були переведені в індивідуальні станки. Протягом поросності матки піддослідних груп були поставлені в ідентичні умови годівлі, догляду та утримання.

Оцінку ступеня фенотипової консолідації основних ознак продуктивності свиней проводили за Ю. П. Полупаном [24], до всієї оціненої групи тварин (по обом сезонам за різної живої маси) за формулами (1-2):

$$
\begin{aligned}
& K_{1}=1-\frac{\sigma_{2}}{\sigma_{3}} \\
& K_{2}=1-\frac{C v_{2}}{C v_{3}}
\end{aligned}
$$

де: $\boldsymbol{K}_{\mathbf{1}}, \boldsymbol{K}_{\mathbf{2}}$ - ступінь фенотипової консолідованості оцінюваної групи;

$\sigma_{z}$ та $C_{v_{2}}$ - середньоквадратичне відхилення та коефіцієнт мінливості оцінюваної групи тварин за конкретною ознакою;

$\sigma_{3}$ та $C_{v_{3}}-$ ті самі показники генеральної сукупності (корів усіх типів конституції).

Показники, отримані дослідним шляхом були опрацьовані методом варіаційної статистики [25-26], з використанням програмного забезпечення MS Excel.

Результати досліджень та їх обговорення. По різних групах тварин багатоплідність коливалась в межах від 10,56 до 11,78 голів (рис.). 


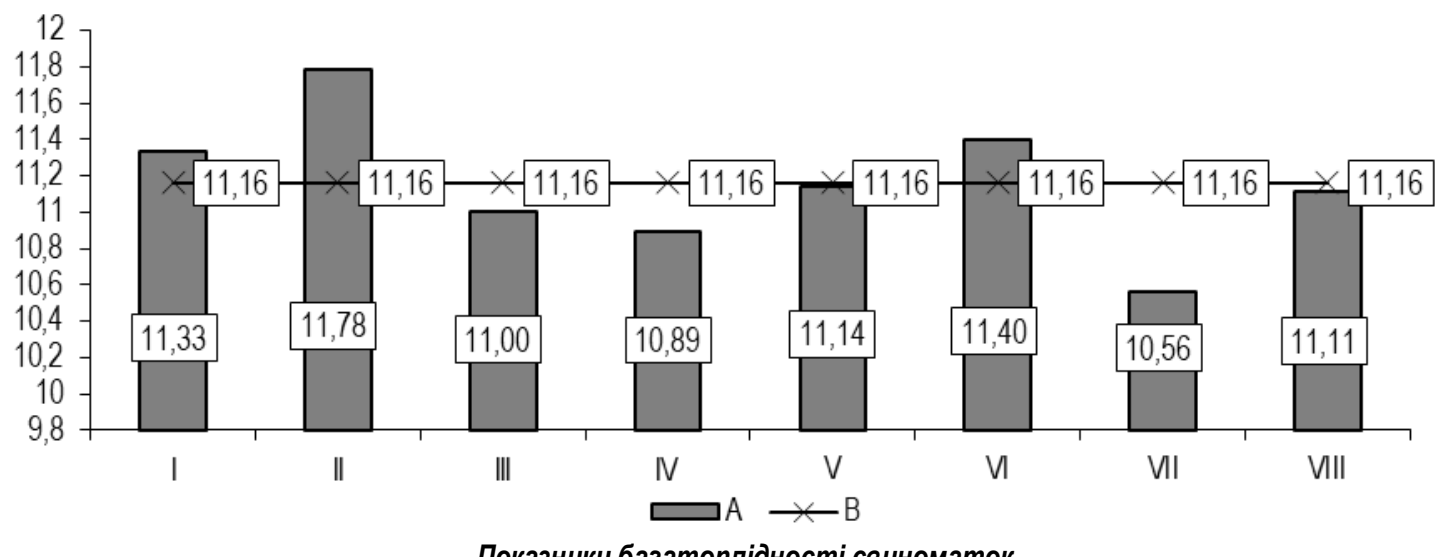

Показники багатоплідності свиноматок

Краща група (матки у віці 18 міс. за зимових опоросів) перевершувала рівень багатоплідності гіршої групи (матки у віці 24 міс. за літніх опоросів) на 11,55 \% ( $p<0,05)$. В той же час, влітку було отримано на 1,81 \% більші значення показника багатоплідності (11,26 $\pm 0,189$ порося на матку), порівняно з зимовими опоросами $(11,06 \pm 0,189$ порося на матку), хоча й різниця була не вірогідною. В межах окремих серій досліджень, кращі значення багатоплідності були отримані за використання більш вікових кнурів (48 міс.), хоча й різниці також були не вірогідними. Вірогідні розбіжності встановлено між молодими матками (18 міс.), що були осімінені дорослими кнурами (48 міс) за літніх опоросів, та молодими матками (18 міс.), що були осімінені молодими кнурами (18 міс.) за зимових опоросів. Ці розбіжності були на рівні $4,68 \%(p<0,05)$.

Після оцінки показнику багатоплідності свиноматок були розраховані коефіцієнти фенотипової консолідації (табл.).

Коефіцієнти фенотипової консолідації показнику багатоплідності свиноматок

\begin{tabular}{|c|c|c|c|}
\hline \multirow{2}{*}{ Групи } & \multirow{2}{*}{$\mathrm{n}$, гол } & \multicolumn{2}{|c|}{ Багатоплідність,гол } \\
\hline & & $K_{1}$ & $\mathrm{~K}_{2}$ \\
\hline \multicolumn{4}{|c|}{ Зимові опороси } \\
\hline 1 & 9 & $-0,173$ & $-0,147$ \\
\hline II & 9 & $-0,046$ & $+0,350$ \\
\hline III & 8 & $-0,024$ & $+0,080$ \\
\hline IV & 9 & $-0,009$ & $+0,080$ \\
\hline \multicolumn{4}{|c|}{ Літні опороси } \\
\hline $\mathrm{V}$ & 7 & $-0,024$ & $-0,170$ \\
\hline $\mathrm{VI}$ & 10 & $+0,193$ & $+0,177$ \\
\hline VII & 9 & $+0,156$ & $-0,017$ \\
\hline VIII & 9 & $-0,009$ & $+0,315$ \\
\hline
\end{tabular}

Відносно консолідований показник багатоплідності (за визначення коесріцієнтів фенотипової консолідованості обома способами) було отримано лише по одній групі тварин - свиноматок середнього віку (24 міс.) за їх осіменіння кнурами середнього віку (24 міс.) за літніх опоросів. Найменш консолідованими (за визначення коефіцієнтів фенотипової консолідованості обома способами) були показники багатоплідності у вікових маток (48 міс.) за їх осіменіння віковими кнурами (48 міс.) як у літній так і у зимовий періоди.
Висновки. Встановлено вірогідні розбіжності за показником багатоплідності між матками у віці 18 міс., за зимових опоросів порівняно 3 матками у віці 24 міс. за літніх опоросів на рівні $11,55 \%$ ( $<<0,05)$, що вказує на доцільність продовження досліджень у цьому напрямку за більшої чисельності досліджуваного поголів'я.

Значних розбіжностей за коефіцієнтами фенотипової консолідації показника багатоплідності маток між різними групами чи сезонами року встановлено не було.

\section{Список використаної літератури:}

1.Жукорський О.М., Никифорук О.В. Галузь свинарства - реальна та прогнозована загроза для довкілля. Агроекологічний журнал. 2013. №. 3, С. 102-107.

2.McIntyre B.D., Herren H.R., Wakhungu J., Watson R.T. Synthesis Report. International Assessment of Agricultural Knowledge, Science and Technology for Development (IAASTD). Washington: Island Press, 2009. 106 p.

3.Schneider Uwe A., Pushpam K. Greenhouse gas emission mitigation through agriculture [Електронний ресурс]. Choices. 2008. Vol. 23. Issue 1. Режим доступу: http:// purl.umn.edu/94500

4.Mekonnen M.M., Hoekstra A.Y. The green, blue and grey water footprint of farm animals and animal products [Електронний ресурc] Value of Water Res. Rep. Ser. - UNESCO-IHE, Delft. The Netherlands. 2010. No. 48, Режим доступу: http://www. unesco-ihe.org/Value-of-water-reserach-reportseries/Research_Papers

5.Hladiy M.V., Polupan Y.P., Kovtun S.I., Kuzebnij S.V., Vyshnevskiy L.V., Kopylov K.V., Shcherbak O.V. Scientific and organizational aspects of generation, genetics, reproduction biotechnology and protection of the genofonds in livestock breeding. Animal Breeding and Genetics, 2018. №56, P. 5-14. doi: 10.31073/abg.56.01. 
6.Vashchenko O. Combinational ability of specialized breeds and types of pigs in industrial crossbreeding. Animal Breeding and Genetics, 2017. №53, P. 84-90. doi: 10.31073/abg.53.11 [in Ukrainian].

7.Храмкова О.М. Відтворювальні якості свиноматок за різних поєднань порід і типів. Theoretical and Applied Veterinary Medicine. 2019. №7(2), С. 115-119. doi 10.32819/2019.71021.

8.Церенюк О.М., Акімов О. В., Шкавро Н. В., Череута Ю. В. Індекси будови тіла двопородних ремонтних свинок та свиноматок. Науково-технічний бюлетень IT HAAH. 2019. №122, C. 248-257. DOI 10.32900/2312-8402-2019-122-248-257.

9.Мартинюк І.М., Церенюк О.М., Акімов О.В. Заплідненість та багатоплідність свиноматок залежно від кратності осіменіння у різні пори року. Науково-технічний бюлетень IT HАAH. 2019. №121, C. 156-162. DOI 10.32900/2312-8402-2019121-156-162.

10. Tsereniuk O., Susol R., Bordun O., Paliy A., Shkromada O., Akimov O., Tsereniuk M., Dependence of sows` phenotypic consolidation of productivity on the reason of their culling due in index selection. Porc Res. 2019. №9(1), P. 15-20.

11. Tsereniuk O., Tsereniuk M., Akimov O., Paliy A., Nanka O., Shkromada O., Pomitun I., Dependence of sows' productivity on the reason of their culling, in index selection. Porc Res. 2018. №8 (1), P. 17-23.

12. Hanenberg E.H.A.T., Knol E.F., \& Merks J.W.M. Estimates of genetic parameters for reproduction traits at different parities in Dutch Landrace pigs. Livestock Production Science, 2001. №69(2), P. 179-186. DOI 10.1016/S0301-6226(00)00258-X

13. Крамаренко С.С., Крамаренко О.С., Луговий С.І., Лихач А.В., Лихач В.Я. Аналіз головних компонент (РСА) ознак відтворення свиноматок великої білої породи. Вісник аграрної науки Причорномор'я. 2019. Вип. 2, C. 75-81. DOI 10.31521/2313-092X/2019-2(102)

14. Копитець Н.Г. Сучасний стан та тенденції розвитку ринку свинини в Україні Економіка АПК. 2018. №. 11, С. 44-54. DOI https://doi.org/10.32317/2221-1055.201811044

15. Рукавиця А.А. Аналіз впливу використання селекційних (оціночних) індексів у якості критеріїв відбору на відтворювальні якості свиноматок української м'ясної породи. Науково-технічний бюлетень IT НААН. 2016. №115, С. $195-202$.

16. Церенюк О.М., Хватов А.І., Стрижак Т.А., Коваленко В.П. Об'єктивна оцінка материнської продуктивності свиней. Таврійський науковий вісник, 2010. Вып.69, С. 112-126.

17. Коваленко Т.С., Сурженко М.В. Вивчення типів успадкування полігенних ознак продуктивності свиней. Вісник Сумського національного аграрного університету. Серія: Тваринництво. 2013. №. 1, С. 76-78.

18. Young L.D., Pumfrey R.A., Cunningham P.J., \& Zimmerman D.R. Heritabilities and genetic and phenotypic correlations for prebreeding traits, reproductive traits and principal components. Journal of Animal Science, 1978. № 46(4), P. 937-949. DOI 10.2527/jas1978.464937x

19. Fahmy M.H., \& Bernard C.S. Interrelations between some reproductive traits in swine. Canadian Journal of Animal Science. 1972. № 52(1), P. 39-45. DOI 10.4141/cjas72-004

20. Biensen N.J., Haussmann M.F., Lay D.C., Christian L.L., \& Ford S.P. The relationship between placental and piglet birth weights and growth traits. Animal Scienc. 1999. №68(4), P. 709-715. DOI 10.1017/S1357729800050736

21. Крамаренко С.С., Луговий С.І., Лихач А.В., Крамаренко О.С., Лихач В.Я., Крамаренко С.С., Крамаренко А.С. Порівняльний аналіз відтворювальних ознак та кластерний аналіз свиней різних порід. Науковий вісник ЛНУВМБ імені С.З. ҐжИцького, 2018, т 20, № 84, С. 21-26. DOI 10.15421/nvlvet8404

22. Мартинюк І.М., Бугров О.Д. Вплив віку свиноматок і кнурів породи уельс і українська м'ясна на вихід поросят в гнізді. Міжвід. тем. наук. Збірник Інституту свинарства і АПВ НААН Свинарство, 2015. Вип. 67, С. 103-106.

23. Методологія та організація наукових досліджень у тваринництві : посіб. / за ред. І.І. Ібатулліна, О.М. Жукорського. Київ: Аграр. наука. 2017. 328 с.

24. Полупан Ю.П. Оценка степени фенотипической консолидации генеалогических групп животных. Зоотехния. 1996. №10, С. 13-15.

25. Плохинский Н.А. Руководство по биометрии для зоотехников. М.: Колос, 1969. 352 с.

26. Барановский Д.И., Хохлов А.М., Гетманец О.М. Биометрия в MS Excel: учеб. пособ. Харків: ФЛП Бровин А. В., 2017. 228 c.

\section{References:}

1.Zhukors'kyy, O.M., Nykyforuk, O.V., 2013. Haluz`svynarstva - real'na ta prohnozovana zahroza dlya dovkillya [The pig breeding industry - a real and predicted threat to the environment]. Ahroekolohichnyy zhurnal, issue 3, pp. 102-107.

2. Mclntyre, B.D., Herren, H.R., Wakhungu and J., Watson R.T., 2009. Synthesis Report. International Assessment of Agricultural Knowledge, Science and Technology for Development (IAASTD). Washington: Island Press, $106 \mathrm{p}$.

3. Schneider, Uwe A., Pushpam, K., 2008. Greenhouse gas emission mitigation through agriculture [online] Choices. Vol. 23, issue 1. - Available at: http:// purl.umn.edu/94500 [Accessed 01 December 2019].

4. Mekonnen, M.M., Hoekstra, A.Y., 2010. The green, blue and grey water footprint of farm animals and animal products [online]. Value of Water Res. Rep. Ser. - UNESCO-IHE, Delft. - The Netherlands. no. 48. Available at: http://www. unescoihe.org/Value-of-water-reserach-reportseries/Research_Papers [Accessed 01 December 2019].

5. Hladiy, M.V., Polupan, Y.P., Kovtun, S.I., Kuzebnij, S.V., Vyshnevskiy, L.V., Kopylov, K.V. and Shcherbak O.V. 2018. Scientific and organizational aspects of generation, genetics, reproduction biotechnology and protection of the genofonds in livestock breeding. Animal Breeding and Genetics, issue 56, pp. 5-14. doi: 10.31073/abg.56.01.

6.Vashchenko, O., 2017. Combinational ability of specialized breeds and types of pigs in industrial crossbreeding. Animal Breeding and Genetics, issue 53, pp. 84-90. doi: 10.31073/abg.53.11.

7. Khramkova, O.M., 2019. Vidtvoryuval'ni yakosti svynomatok za riznykh poyednan` porid i typiv [Reproductive qualities of 
sows in different combinations of breeds and types]. Theoretical and Applied Veterinary Medicine, issue 7(2), pp. 115-119. DOI 10.32819/2019.71021.

8.Tsereniuk, O.M., Akimov, O.V., Shkavro, N.V.and Chereuta, YU.V., 2019. Indeksy budovy tila dvoporodnykh remontnykh svynok ta svynomatok [Body structure indices for two-offspring pigs and sows.]. Naukovo-tekhnichnyy byuleten ' IT NAAN, issue 122 pp. 248-257. DOI 10.32900/2312-8402-2019-122-248-257.

9. Martinyuk, I.M., Tsereniuk, O.M., Akimov, O.V., 2019 Zaplidnenist ta bahatoplidnist` svynomatok zalezhno vid kratnosti osimeninnya u rizni pory roku [Fertilization and multiplicity of sows depending on the frequency of insemination at different times of the year]. Naukovo-tekhnichnyy byuleten 'IT NAAN, issue 121, pp. 156-162. DOI 10.32900/2312-8402-2019-121-156-162.

10. Tsereniuk, O., Susol, R., Bordun, O., Paliy, A., Shkromada, O., Akimov, O.and Tsereniuk, M. 2019. Dependence of sows' phenotypic consolidation of productivity on the reason of their culling due in index selection. Porc Res, issue 9 (1), pp. 15-20.

11. Tsereniuk, O., Tsereniuk, M., Akimov, O., Paliy, A., Nanka, O., Shkromada, O., and Pomitun, I., 2018. Dependence of sows' productivity on the reason of their culling, in index selection. Porc Res., issue 8 (1), pp. 17-23.

12. Hanenberg, E.H.A.T., Knol, E.F., Merks, J.W.M., 2001. Estimates of genetic parameters for reproduction traits at different parities in Dutch Landrace pigs. Livestock Production Science, issue 69 (2), pp. 179-186. DOI 10.1016/S03016226(00)00258-X

13. Kramarenko, S.S., Kramarenko, O.S., Luhovyy, S.I., Lykhach, A.V. and Lykhach, V.YA. 2019. Analiz holovnykh komponent (PCA) oznak vidtvorennya svynomatok velykoyi biloyi porody [Principal Component Analysis (PCA) of sows reproduction of Large White breed]. Visnyk ahrarnoyi nauky Prychornomor'ya, issue 2, pp. 75-81. DOI 10.31521/2313-092X/2019-2(102).

14. Kopytets', N.H., 2018. Suchasnyy stan ta tendentsiyi rozvytku rynku svynyny v Ukrayini [The current state and tendencies of pork market development in Ukraine]. Ekonomika APK, issue 11, pp. 44-54. DOI https://doi.org/10.32317/22211055.201811044.

15. Rukavytsya, A.A., 2016. Analiz vplyvu vykorystannya selektsiynykh (otsinochnykh) indeksiv u yakosti kryteriyiv vidboru na vidtvoryuval'ni yakosti svynomatok ukrayins'koyi m yasnoyi porody [Analysis of the influence of the use of breeding (evaluation) indices as selection criteria on reproductive qualities of sows of Ukrainian Meat breed]. Naukovo-tekhnichnyy byuleten 'IT NAAN, issue 115 , pp. 195-202.

16. Tsereniuk, O.M., Khvatov, A.I., Stryzhak, T.A., Kovalenko, V.P., 2010. Ob'yektyvna otsinka materyns `koyi produktyvnosti svyney [Objective evaluation of maternal pig productivity]. Tavriys 'kyy naukovyy visnyk, issue 69, pp. 112-126.

17. Kovalenko, T.S., Surzhenko, M.V., 2013 Vyvchennya typiv uspadkuvannya polihennykh oznak produktyvnosti svyney [Study of types of inheritance of polygenic features of pig productivity]. Visnyk Sums koho natsional'noho ahrarnoho universytetu, Seriya: Tvarynnytstvo, issue 1, pp. 76-78.

18. Young, L.D., Pumfrey, R.A., Cunningham, P.J., \& Zimmerman, D.R., 1978. Heritabilities and genetic and phenotypic correlations for prebreeding traits, reproductive traits and principal components. Journal of Animal Science, issue 46 (4), pp. $937-$ 949. DOI 10.2527/jas1978.464937x

19. Fahmy, M.H., \& Bernard, C.S., 1972. Interrelations between some reproductive traits in swine. Canadian Journal of Animal Science, issue 52 (1), pp. 39-45. DOI 10.4141/cjas72-004.

20. Biensen, N.J., Haussmann, M.F., Lay, D.C., Christian, L.L., and Ford, S.P., 1999. The relationship between placental and piglet birth weights and growth traits. Animal Scienc., issue 68(4), pp. 709-715. DOI 10.1017/S1357729800050736

21. Kramarenko, S.S., Luhovyy, S.I., Lykhach, A.V., Kramarenko, O.S., Lykhach, V.YA., Kramarenko, S.S., Kramarenko, A.S., 2018. Porivnyal'nyy analiz vidtvoryuval'nykh oznak ta klasternyy analiz svyney riznykh porid [Comparative analysis of reproductive traits and cluster analysis of pigs of different breeds]. Naukovyy visnyk LNUVMB imeni S. Z. Gzhyts 'koho, vol. 20, issue 84, pp. 21-26. DOI 10.15421/nvlvet8404.

22. Martynyuk, I.M., Buhrov O.D., 2015. Vplyv viku svynomatok i knuriv porody uel's i ukrayins'ka m'yasna na vykhid porosyat $v$ hnizdi [Influence of the age of sows and boars of the breed of Welsh and Ukrainian Meet on the output of piglets in the litter]. Mizhvid. tem. nauk. Zbirnyk Instytutu svynarstva i APV NAAN - Svynarstvo, issue 67, pp. 103-106.

23. Ibatullin I.I., Zhukors`kyy O.M. ed., 2017. Metodolohiya ta orhanizatsiya naukovykh doslidzhen ' u tvarynnytstvi: posib [Methodology and organization of scientific research in animal husbandry: a tool]. Kyiv: Ahrar. nauka..

24. Polupan, YU.P., 1996. Otsenka stepeni fenotipicheskoy konsolidatsii genealogicheskikh grupp zhivotnykh [Assessment of the degree of phenotypic consolidation of genealogical groups of animals]. Zootekhníya, issue 10, pp. 13-15.

25. Plokhinskiy, N.A. 1969. Rukovodstvo po biometrii dlya zootekhnikov M. Kolos.

26. Baranovs'kiy, D.I., Khokhlov, A.M., Getmanets, O.M., 2017. Biometriya v MS Excel : ucheb. posob. Kharkív FLP Brovin A.V.

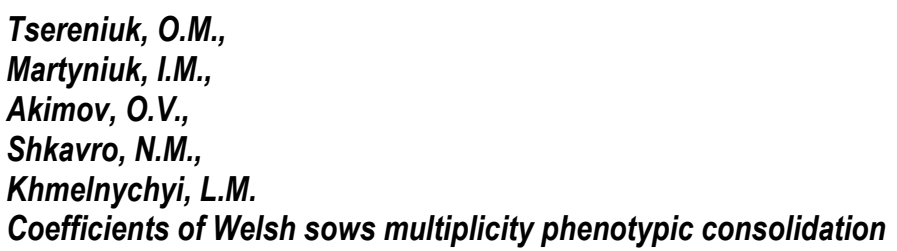

The aim of the research, the results of which are presented in the article, was to study the effect of sows and boars age on their multiplicity, taking into account the season of the year and the age of the animals. The studies were conducted in the research farm of SE "Gontarivka" of the Volchansky district of Kharkiv region. Natural breeding of sows is used for reproduce on the farm. The insemination of sows was carried out according to the scheme of studies. 35 head of sows and 4 boars of different ages and live 
weights were selected. Four groups of uterus were formed. In order to study the impact of the season of the year on sow productivity, the first series of studies were conducted in the autumn, the second series - in the spring according to the same scheme. The same animals used in both series of studies. For different animal groups, multiplicity ranged from 10.56 to 11.78 heads. The best group (uterus at 18 months of age in winter farrowing) outperformed the inferiority group of the worse group (uterus at the age of 24 months in summer farrowing) by $11.55 \%$ ( $p<0.05)$. At the same time, in summer the values of multiplicity $(11.26 \pm 0.189$ piglets per uterus) were obtained by $1.81 \%$, compared to winter piglets (11.06 \pm 0.189 piglets per uterus), although the difference was not probable. Within the individual series of studies, the best values of multiplicity were obtained by using age boars (48 months), although the differences were also not significant. Possible differences were found between young uterus (18 months) inseminated by adult boars (48 months) in summer farrowing and young uterus (18 months) inseminated by young boars (18 months) in winter farrowing. These differences were at the level of $4.68 \%(p<0.05)$. The relatively consolidated multiplicity index (to determine phenotypic consolidation coefficients in both ways) was obtained in only one group of animals - middle-aged sows (24 months) for insemination by middle-aged boars (24 months) during summer farrowing. The least consolidated (by determining the phenotypic consolidation coefficients in both ways) were the multiplicity rates of age uterus (48 months) for their insemination by age boars (48 months) in both summer and winter periods.

Key words: pig breeding, sows, reproductive capacity, multiplicity, coefficients of phenotype consolidation, seasons, age of animals.

Дата надходження до редакції: 05.02.2019 p 